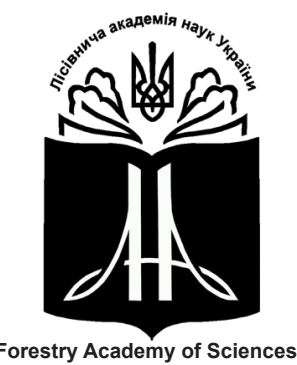

of Ukraine

Наукові праці Лісівничої академії наук України

Proceedings of the Forestry Academy of Sciences of Ukraine

http://fasu.nltu.edu.ua

https://doi.org/ 411703

Article received 2017.09.09

Article accepted 2017.11.15
ISSN 1991-606X print

ISSN 2616-5015 online

(a) $\triangle$ Correspondence author

Roman Viter

viterrm@ukr.net

УДК $630 * 114: 630 * 116.2$

\title{
Ґрунтозахисна роль лісу на водозборах Карпат
}

\author{
В.С. Олійник' , Р.М. Вітер²
}

Наведено кількісну оцінку трунтозахисної ролі лісового покриву на гірських водозборах карпатського регіону. Розраховано показники твердого стоку (модуль твердого стоку, каламутність води) на парних водозборах та в різних рельєфно-кліматичних умовах Карпат. Висвітлено залежності обсягів річного змиву грунту від стрімкості схилів і лісистості водозборів. 3'ясовано, щзо трунтозахисні властивості лісів ослаблюються із збільшенням стрімкості рельєфу та зменшенням лісистості. Проаналізовано відмінності прояву ерозійних процесів на різних висотних смугах гірської системи, щзо зумовлюють вибір диференційованих методів оптимізації лісистості.

Встановлено, щзо гірські ліси Карпат є потужним трунтозахисним фактором, здатним зменшувати ерозійні прочеси, порівняно із польовими угіддями, майже у сім разів, сприяючи тим самим зниженню каламутності річкових вод майже у 19 разів. Сучасна (59\%) лісистість гірської системи покращує иі процеси в два рази.

У просторовому вимірі захисна роль лісу змінюється залежно від стрімкості та висоти гірських схилів. На північно-східному мегасхилі Карпат вона сильніше виражена, ніж на більш стрімкому південно-західному. Вплив стрімкості схилів у розвитку ерозійних явищ досить відчутний у нижніх висотних смугах обох мегасхилів (до 800 м н.р.м.) із антропогенно зниженою лісистістю (20-60\%). У верхніх смугах гір (понад 800 м) негативна роль гірського рельєфу у розвитку ерозії елімінується високою лісистістю водозборів (60-80\%).

Для зменшення ерозійних процесів і покращення чистоти природних вод запропоновано диференційовану систему лісівничо-меліоративних заходів.

Ключові слова: гірські ліси, водозбори, лісистість, ерозійні процеси, твердий стік, каламутність води, стрімкість схилу

Вступ. У комплексі багатогранних функцій лісу вагоме місце належить його грунтозахисній ролі. Запобігаючи ерозійним процесам, ліс зберігає родючість грунтів й одночасно забезпечує чистоту водних об'єктів. Для гірських умов Карпат ці властивості лісу досить важливі через наявність тут розвинених ерозійно-формувальних чинників - частих зливових опадів, різкорозчленованого рельєфу та антропогенно зниженої лісистості. За інтенсивністю змиву грунтів і каламутністю річкових вод регіон посідає перше місце в Україні.

На цей час для Карпат у науковій літературі висвітлено особливості змиву грунту і формування стоку твердих наносів із різних угідь (Goloyad \& Boichuk, 2001, Perekhrest, Kochubei, \& Pechkovska, 1971) та зміни грунтозахисної ролі лісу під впливом різних способів лісоексплуатації (Gorshenin, 1974, Kulchytsky-Zhyhailo, Prybolotna, \& Oshkurevich, 2007, Olijnyk, 2013, Polyakov, 1965). Проте кількісну оцінку протиерозійних і водоочисних властивостей лісу, як одного із основних компонентів карпатських ландшафтів, досліджено слабо. Особливо це стосується водозбірних басейнів, які за науковим обгрунтуванням (Pobedinsky, 1979, Chubatyy, 1984, Olijnyk, 2013) є пріоритетними для природоощадного ведення лісового господарства 3 позицій раціонального

Олійник Василь Степанович - дійсний член Лісівничої академії наук України, доктор сільськогосподарських наук, професор, завідувач кафедри лісознавства. Прикарпатський національний університет імені Василя Стефаника, вул. Шевченка, 57, м. Івано-Франківськ, 76018, Україна. Тел.: +38-067-456-75-94. E-mail: klz.pu.if.ua@ukr.net

2 Вітер Роман Михайлович - кандидат сільськогосподарських наук, доцент, доцент кафедри лісознавства. Прикарпатський національний університет імені Василя Стефаника, вул. Шевченка, 57, м. Івано-Франківськ, 76018, Україна. Тел.: +38-097-378-75-14. E-mail: viterrm@ukr.net 
використання ресурсів деревини, збереження і посилення екологічної рівноваги у гірських умовах.

Невід'ємною передумовою запровадження ведення господарства за водозбірним принципом $є$ встановлення критичних і оптимальних у грунтозахисному вимірі показників лісистості. Окрім того, через те, що у різних природних умовах Карпат грунтозахисна роль лісу проявляється неоднаково (Olijnyk \& Tkachuk, 2015, Chubatyy, 1968), для організації такого господарства досить важливим $є$ врахування впливу на змив грунтів місцевих особливостей рельєфу та ступеня трансформації лісових угідь у польові.

Мета роботи полягає у кількісній оцінці грунтозахисної ролі лісистості гірських водозборів із урахуванням місцевих природо-лісівничих умов території Карпат.

Об'скти і методика. Об 'єкт дослідження - гірські ліси Українських Карпат. Предмет дослідження - грунтозахисна роль гірських лісів.

У гірських умовах ерозійні процеси представлені, в основному, площинним змивом грунту та бічним розмивом берегів і, меншою мірою, глибинним врізанням ярів (Tsys, 1968). Понад 90\% продуктів ерозії із водозбірних площ потрапляють до гідрографічної мережі і переносяться річковими водами до передгірних районів (Deev, 1968). Тому показники твердого стоку річок можуть слугувати інтегральним показником ерозійних процесів на водозборах і впливу на них лісистості.

Критеріями протиерозійних властивостей лісу були два показники:

- модуль багаторічного стоку наносів, що є масою переміщеної твердої речовини за рік у водному потоці, $\left(\mathrm{T} \cdot \mathrm{\kappa м}^{-2}\right)$;

- каламутність води - завислі у водному потоці тверді частини, $\left(\Gamma \cdot \mathrm{M}^{-3}\right)$.

Перший із них характеризує об'єми змитого із водозбору грунту, другий - чистоту річкових вод. Для розрахунків зазначених показників використовували матеріали гідрометеослужби за другу половину XX ст., коли найповніше спостерігали за річковим стоком та його твердими наносами (Resources of surface waters of the USSR, 1976). Для аналізу було задіяно 33 річкові басейни площею від 25 до 6890 км $^{2}$ із середніми висотами 450-1100 м н.р.м. та стрімкістю схилів у межах 5-22․ Їхня лісистість змінювалася від 25 до $79 \%$, а річні опади - від 845 до 1600 мм. Показники висот і лісистості водозборів запозичували з гідрологічних довідників, а опадів - із літературних джерел (Galushchenko, 1977, Kirilyuk, 1985) iз нашими доповненнями. На основі картографічних і лісовпорядних матеріалів розраховували середню стрімкість схилів водозборів й уточнювали відсоток лісистості.

Аналіз залежності твердого стоку від рівня лісистості водозборів здійснювали кореляційним методом для всієї території Карпат та окремо взятих 17 басейнів південно-західного і 16 водозборів північно-східного мегасхилу регіону, між якими $є$ гідрокліматичні і рельєфні відмінності, а саме: показники атмосферного зволоження і стрімкості схи- лів для першої групи водозборів вищі, ніж для другої. Цим же способом аналізували вплив лісистості на твердий стік у нижньогірних смугах гір (до 800 м н.р.м.) із антропогенно зниженою лісистістю і на вищих рівнях гір (понад 800 м н.р.м.) із меншими змінами лісистості водозборів. Використовували також і порівняльний метод показників лісистості і наносів на парних басейнах-аналогах, тобто таких, що характеризуються приблизно однаковими геоморфологічними і лісорослинними умовами, але контрастні у показниках лісистості (Olijnyk, 2013).

Результати та обговорення. У якісному вимірі позитивну роль лісу у запобіганні ерозійних процесів грунту та забезпеченні чистоти річкових вод добре ілюструють зміни показників твердого стоку на басейнах-аналогах. Наведені у табл. 1 дані для п’яти пар таких об'єктів свідчать, що навіть незначне підвищення лісистості (на 12\%) сприяє падінню модулів твердого стоку і каламутності рік. А збільшення іiі на 22-35\% суттєво зменшує не лише ці види наносів, а й кількість днів із слабкими i сильними рівнями забруднення природних вод. Отже, запобігаючи розвитку ерозії грунту, гірські ліси водночас відіграють водоохоронні функції.

У просторовому вимірі показники ерозійних процесів і каламутності вод по території Карпат мінливі, що пов'язано із змінами рельєфно-кліматичних умов (табл. 2). Насамперед виражені відмінності у формуванні шкідливих процесів на двох протилежних мегасхилах гірської системи - південнозахідному (басейн Тиси) і північно-східному (басейни Дністра, Пруту і Серету). За майже однакової лісистості цих мегасхилів, атмосферне зволоження, стрімкість рельєфу, а відповідно й твердий стік у першому випадку більший, ніж у другому. Водночас підвищена водність річок Закарпаття зумовлює деяке зниження каламутності їх вод порівняно із річками протилежного північно-східного мегасхилу Карпат, водоносність яких менша (Kirilyuk, 1985).

У межах кожного мегасхилу і гірської системи загалом добре виокремлюються дві висотні смуги розвитку ерозії - нижні і верхні. Перші із них розміщені у висотному діапазоні від підніжжя гір до 800 м н.р.м. Вони характеризуються невисокою лісистістю ( $\approx 47 \%$ ) та найбільшими показниками твердого стоку. Верхні смуги - приурочені до гіпсометричних рівнів понад 800 м н.р.м. Для них властива підвищена лісистість (70\%) і менший, порівняно із нижньою смугою, стік наносів. У якісному вимірі нижні смуги - це антропогенно змінені ландшафти із інтенсивними ерозійними процесами, а верхні - із меншими наслідками господарської діяльності та слабшим розвитком шкідливих явищ (Olijnyk, 2013).

Для розроблення заходів щодо зменшення ерозійних явищ і забезпечення чистоти річкових вод важлива не лише якісна оцінка грунтозахисних властивостей лісу, але й їх кількісні показники. Для цього здійснено кореляційний аналіз залежності різних характеристик стоку наносів від лісистості та стрімкості схилів у різних лісорослинних умовах Карпат. Розрахунки показали таке. 
Показники твердого стоку на парних водозборах різної лісистості

\begin{tabular}{|c|c|c|c|c|c|c|c|c|}
\hline \multirow[b]{2}{*}{$\begin{array}{c}\text { Водозбір } \\
\text { (річка-пункт) }\end{array}$} & \multicolumn{4}{|c|}{ Характеристики водозборів } & \multicolumn{4}{|c|}{ Показники твердого стоку } \\
\hline & $\begin{array}{l}\text { Площа, } \\
\text { км }^{2}\end{array}$ & $\begin{array}{c}\text { Середня } \\
\text { висота, м } \\
\text { н.р.м. }\end{array}$ & $\begin{array}{c}\text { Річні } \\
\text { опади, } \\
\text { мм }\end{array}$ & $\begin{array}{l}\text { Лісистість, } \\
\%\end{array}$ & $\begin{array}{c}\text { Модуль } \\
\text { твердого } \\
\text { стоку, } \\
\text { т } \cdot \text { кM }^{-2}\end{array}$ & $\begin{array}{c}\text { Каламут- } \\
\text { ність води, } \\
\Gamma \cdot \mathrm{M}^{-3}\end{array}$ & $\begin{array}{c}\text { Дні } \\
\text { з каламут- } \\
\text { ністю } \\
>50 \Gamma \cdot \mathrm{M}^{-3}\end{array}$ & $\begin{array}{c}\text { Дні з } \\
\text { каламут- } \\
\text { ністю > } \\
1000 \Gamma \cdot \mathbf{M}^{-3}\end{array}$ \\
\hline \multicolumn{9}{|c|}{$\begin{array}{l}\text { I. Південно-західний мегасхил Карпат } \\
\text { iльні водозбори із пануванням буково-ялинових лісів }\end{array}$} \\
\hline Ріка - смт Міжгір'я & 550 & 800 & 1363 & 41 & 130 & 210 & 41 & 3 \\
\hline Теребля - с. Колочава & 369 & 1000 & 1411 & 67 & 87 & 110 & 40 & 1 \\
\hline \multicolumn{9}{|c|}{ б) привододільні водозбори із буковими лісами } \\
\hline Латориця - с. Підполоззя & 324 & 720 & 1338 & 50 & 190 & 190 & 57 & 4 \\
\hline Віча - с. Неліпине & 241 & 760 & 1388 & 72 & 151 & 160 & 59 & 2 \\
\hline \multicolumn{9}{|c|}{ в) водозбори всього мегасхилу із домінуванням букових лісів } \\
\hline Уж-с. Зарічево & 1280 & 560 & 1221 & 51 & 140 & 260 & 105 & 3 \\
\hline Латориця - м. Мукачево & 1360 & 570 & 1228 & 63 & 130 & 196 & 110 & 3 \\
\hline \multicolumn{9}{|c|}{$\begin{array}{l}\text { II. Північно-східний мегасхил Карпат } \\
\text { льні водозбори із пануванням мішаних ялинових лісів }\end{array}$} \\
\hline Стрий - с. Завадівка & 740 & 800 & 1254 & 35 & 190 & 270 & 108 & 4 \\
\hline Опір - м. Сколе & 733 & 820 & 1220 & 69 & 68 & 110 & 50 & 1 \\
\hline \multicolumn{9}{|c|}{ д) низькогірні водозбори із ялицево-буковими лісами } \\
\hline Лужанка - с. Гошів & 146 & 660 & 1052 & 59 & 134 & 260 & 35 & 2 \\
\hline Сукель - с. Тисів & 138 & 770 & 1140 & 79 & 59 & 103 & 16 & 0 \\
\hline
\end{tabular}

Таблиия 2

Середні показники твердого стоку на водозборах різних лісорослинних умов Карпат

\begin{tabular}{|c|c|c|c|c|c|c|c|c|}
\hline \multirow{2}{*}{$\begin{array}{c}\text { Район } \\
\text { визначення } \\
\text { середніх показників }\end{array}$} & \multicolumn{6}{|c|}{ Середні характеристики водозборів } & \multirow{2}{*}{$\begin{array}{c}\text { Модуль } \\
\text { твердого } \\
\text { стоку, } \\
\text { т } \cdot \text { кM }^{-2} \\
\end{array}$} & \multirow{2}{*}{$\begin{array}{c}\text { Каламут- } \\
\text { ність води, } \\
\Gamma \cdot \mathbf{M}^{-3}\end{array}$} \\
\hline & $\begin{array}{c}\text { Площа, } \\
\text { км }^{2}\end{array}$ & $\begin{array}{l}\text { Висота, } \\
\text { м н.р.м. }\end{array}$ & $\begin{array}{c}\text { Стрімкість } \\
\text { схилів, град. }\end{array}$ & $\begin{array}{c}\text { Річні } \\
\text { опади, мм }\end{array}$ & $\begin{array}{c}\text { Лісистість, } \\
\text { \% }\end{array}$ & $\begin{array}{l}\text { Розора- } \\
\text { ність, \% }\end{array}$ & & \\
\hline \multicolumn{9}{|c|}{ Південно-західний мегасхил Карпат (17 водозборів) } \\
\hline Весь мегасхил & 652 & 790 & 16 & 1343 & 54 & $\approx 8$ & 146 & 178 \\
\hline у т.ч.: до висоти 800 м & 657 & 690 & 15 & 1322 & 48 & 9 & 165 & 207 \\
\hline понад 800 м & 641 & 1040 & 19 & 1394 & 70 & $<5$ & 100 & 108 \\
\hline \multicolumn{9}{|c|}{ Північно-східний мегасхил Карпат (16 водозборів) } \\
\hline Весь мегасхил & 660 & 740 & 12 & 1118 & 56 & 18 & 111 & 206 \\
\hline у т.ч.: до висоти 800 м & 926 & 630 & 9 & 1033 & 46 & 25 & 113 & 271 \\
\hline понад 800 м & 318 & 888 & 16 & 1228 & 70 & 10 & 83 & 110 \\
\hline \multicolumn{9}{|c|}{ Вся територія Карпат (33 водозбори) } \\
\hline Для всього регіону & 656 & 770 & 14 & 1237 & 55 & 13 & 129 & 190 \\
\hline у т.ч.: до висоти 800 м & 772 & 660 & 13 & 1198 & 47 & 16 & 191 & 234 \\
\hline понад 800 м & 453 & 950 & 17 & 1297 & 70 & 8 & 90 & 109 \\
\hline
\end{tabular}

Основний показник наносів - модуль твердого стоку, який характеризує змив грунту з одиниці площі $\left(S\right.$, т $\cdot$ км$\left.^{-2}\right)$, знаходиться у чіткій залежності від лісистості водозборів $(f, \%)$. Із їі збільшенням він чітко зменшується. Рівняння регресії цього процесу для різних частин регіону такі:

1) для 33 водозборів всієї території Карпат:

$$
S=235-2,0 \cdot f_{л} \quad \text { при } r=-0,67 \pm 0,10 ;
$$

2) для 17 водозборів південно-західного мегасхилу гірської системи:

$$
S=268-2,26 \cdot f_{л} \quad \text { при } r=-0,82 \pm 0,08 ;
$$

3) для 16 річкових басейнів північно-східного мегасхилу регіону:

$$
S=208-1,79 \cdot f_{л} \quad \text { при } r=-0,65 \pm 0,14 .
$$

Розрахунки за наведеними формулами засвідчили, що ліс, порівняно із польовими угіддями, зменшує ерозійні процеси у таких розмірах:

- для гірської системи загалом: від 235 до $35 \mathrm{~T} \cdot \mathrm{\kappa м}^{-2}($ у 6,7 раза $)$; 
- на південно-західному мегасхилі гір: від 268 до 42 т $\cdot$ км$^{-2}$ (у 6,4 раза);

на північно-східній їх частині: від 208 до $29 \mathrm{~T} \cdot \mathrm{\kappa м}^{-2}$ (у 7,2 раза).

Оскільки частка лісистості гірської території сучасних Карпат становить 59\%, із формули (1) випливає, що у регіональному вимірі вона зменшує ерозійні процеси у два рази - від 235 до 117 т $\cdot$ км$^{-2}$.

Значний науковий і прикладний інтерес становить питання виконання лісом грунтозахисної ролі лісу в умовах різної стрімкості, яка, як відомо, є одним із головних ерозійно-формувальних чинників. Аналіз модулів твердого стоку на 26 водозборах Карпат із різними показниками похилу поверхні показав, що на тлі природного різноманіття гірської території роль стрімкості схилів у формуванні наносів неоднозначна. Найбільші відмінності у цьому процесі спостерігаються між охарактеризованими двома висотними смугами водозборів із різною лісистістю. У цьому сенсі кореляційні розрахунки засвідчили таке.

У нижній смузі обох мегасхилів гірської системи iз антропогенно зміненими ландшафтами (до 800 м н.р.м.) і невисокою лісистістю ерозійні явища значно залежать від стрімкості схилів $(r=0,66)$. Тому збільшення тут площ лісового покриву запобігає інтенсифікації шкідливих процесів. У цих умовах залежність модуля твердого стоку рік $\left(\mathrm{S}, \mathrm{T} \cdot \mathrm{KM}^{-2}\right)$ від стрімкості схилів (I, град.) і лісистості водозборів $(f, \%)$ виражається такою емпіричною формулою:

$$
S=5,47 \cdot \mathrm{I}-2,66 \cdot f_{л}+183 \text { при } R=0,77 \pm 0,07 \text {. }
$$

Вона свідчить, що за стрімкості схилів $5^{\circ}$ ліс, порівняно з полем, зменшує твердий стік (ерозійні процеси) у 53 рази, а за стрімкості 10,15 і $20^{\circ}$ - відповідно в 7,4, 4,5 і 3,4 раза. Звідси випливає важлива теза, що із збільшенням стрімкості схилів грунтозахисні властивості лісу ослаблюються, а тому, чим більші похили поверхні гірських схилів, тим більша частина їх площі повинна заліснюватися. Як видно із рисунку, що ілюструє модель цього процесу, найвища лісистість повинна бути на схилах понад $20^{\circ}$, що характеризується інтенсивними ерозійними явищами - понад $100 \mathrm{~T} \cdot \mathrm{\kappa м}^{-2}$.

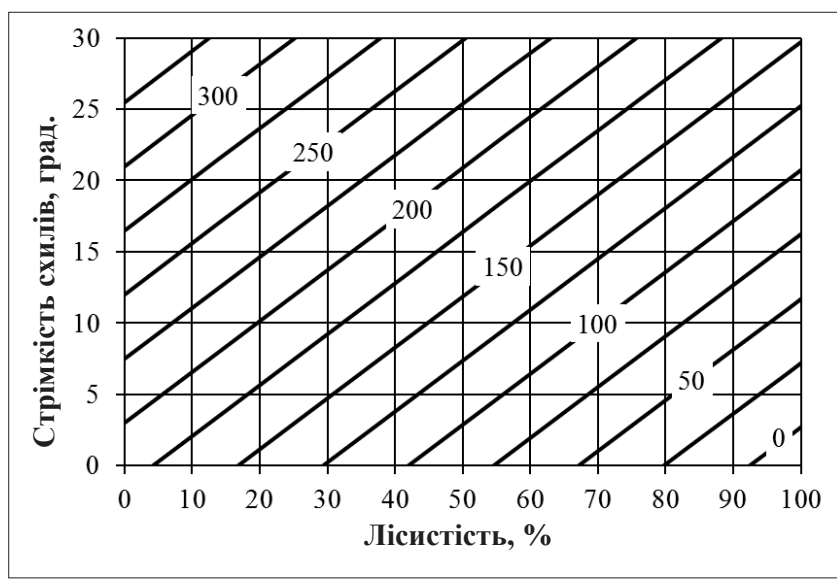

Рис. 1. Залежність обсягів річного змиву грунту $\left(\mathrm{T} \cdot \mathrm{\kappa M}^{-2}\right)$ від стрімкості схилів і лісистості водозборів
На висоті гірської системи понад 800 м н.р.м. в умовах високої лісистості водозборів (57-79\%) залежність твердого стоку від стрімкості схилів невисока $(r=0,39)$. Очевидно, що значна лісистість цієї смуги гір елімінує негативні наслідки стрімкості схилів в інтенсифікації ерозійних процесів.

Такі закономірності у прояві ерозійних процесів на різних висотних смугах гірської системи зумовлюють два підходи до оптимізації лісистості. У нижній смузі доцільне іiі підвищення з урахуванням стрімкості схилів, а саме внаслідок залісення стрімких ділянок і еродованих земель. У верхній смузі розширення площ лісів доцільно приурочувати, в основному, до середньолісистих водозборів $(<70 \%)$ із наявністю на них лісомеліоративного фонду - ярів, кам'янистих розсипищ, порушених i сильно еродованих земель. В обох випадках важливим шляхом збереженості грунтів є створення захисних смуг уздовж гідрографічної мережі та по горизонталях обширних аграрних угідь.

Захищаючи грунти від ерозійних процесів, ліс тим самим забезпечує чистоту водних ресурсів. Iз збільшенням лісистості водозборів $(f, \%)$ річна каламутність рік $\left(M, \Gamma \cdot \mathrm{M}^{-3}\right)$ різко падає. Рівняння регресії цього процесу для різних частин Карпат такі:

1) для всієї території Карпат:

$$
M=390-3,69 \cdot f_{л} \quad \text { при } r=-0,68 \pm 0,08 ;
$$

2) для південно-західного мегасхилу гір (Закарпаття):

$$
M=328-2,77 \cdot f_{л} \quad \text { при } r=-0,70 \pm 0,13 ;
$$

3) для північно-східного мегасхилу Карпат:

$$
M=453-4,84 \cdot f_{л} \quad \text { при } r=-0,71 \pm 0,13 .
$$

Вони свідчать, що у гірській системі Карпат ліс, порівняно із польовими угіддями, зменшує каламутність річкових вод від 390 до $21 \Gamma \cdot \mathrm{M}^{-3}$, тобто в 19 разів. Сучасна (59\%) лісистість гірського регіону сприяє покращенню чистоти річкових вод в 1,8 раза. Разом 3 тим, у різних частинах Карпат зменшення каламутності рік неоднакове. Так, для гідрографічної мережі Закарпаття, ліс зменшує каламутність вод від 328 до 51 г $\cdot \mathrm{M}^{-3}$ (у 6,4 раза), а для річок північно-східного мегасхилу - від $453 \Gamma \cdot \mathrm{M}^{-3}$ до 0 при лісистості $94 \%$. Загалом зниження каламутності річок під впливом зростання лісистості інтенсивніше відбувається на вологішому північносхідному мегасхилі Карпат, порівняно із стрімкішим південно-західним мегасхилом. Як відомо, ліс зменшує і тривалість часу у році із каламутними водами. Досить чітко це проявляється на днях $\left(T_{n}\right)$ сильної каламутності рік $\left(>1000 \Gamma \cdot \mathrm{M}^{-3}\right)$, залежність якої характеризується такою регресією:

$$
T_{м}=7-0,075 \cdot f_{л} \quad \text { при } r=-0,62 \pm 0,11 .
$$

Із нього випливає, що за відсутності лісу цей показник річкового стоку може спостерігатися сім днів за рік, а за наявності 94\% лісистості водозборів він уже не проявляється.

Висновки. Гірські ліси Карпат є потужним грунтозахисним фактором, здатним зменшувати ерозійні процеси, порівняно із польовими угіддями, 
майже у сім разів, сприяючи тим самим падінню каламутності річкових вод приблизно у 19 разів. Сучасна (59\%) лісистість гірської системи покращує ці процеси в 1,9-2 рази.

У просторовому вимірі захисна роль лісу змінюється залежно від стрімкості і висоти гірських схилів. На північно-східному мегасхилі Карпат вона чіткіше виражена, ніж на більш стрімкому південнозахідному мегасхилі. Вплив стрімкості схилів у розвитку ерозійних явищ досить відчутний у нижніх висотних смугах обох мегасхилів (до 800 м н.р.м.) iз антропогенно зниженою лісистістю (20-60\%). У верхніх смугах гір (понад 800 м н.р.м.) негативна роль гірського рельєфу у розвитку ерозії елімінується високою лісистістю водозборів (60-80\%).

Для зменшення інтенсивності ерозійних процесів і покращення чистоти природних вод необхідна диференційована система лісівничо-меліоративних заходів. У нижній гірській смузі основні із них - залісення крутосхилів та еродованих земель. У верхній - залісення ділянок лісомеліоративного фонду i підняття антропогенно зниженої верхньої межі лісу на водозборах $з$ лісистістю $<70 \%$. В обох випадках досить важливим є створення захисних смугових насаджень вздовж гідрографічної мережі та на обширних аграрних угіддях.

\section{Бібліографічні посилання}

Galushchenko, N.G. (1977). Water balance of the rivers of the Dniester basin. Proceedings of UkrNIGMI. Gidrometeoizdat, 153, 125-139 (in Russian).

Goloyad, B.Ya., \& Boichuk, I. I. (2001). Ecological bases of protection of mountain-forest basin ecosystems from harmful exogenous processes in the Ukrainian Carpathians. Ivano-Frankivsk: NAIR (in Ukrainian).

Gorshenin, N. M. (1974). Soil erosion of the mountain forest zone and its managing. Moscow: Forestry (in Russian).

Deev, Yu.O. (1968). The rivers. The nature of the Ukrainian Carpathians. Lviv: Publishing House of Lviv University (in Ukrainian).

Kirilyuk, M.M. (1985). Water balance Thermal and water regime of the Ukrainian Carpathians. Leningrad: Gidrometeoizdat (in Russian).

Kulchytsky-Zhyhailo, I. E., Prybolotna, N.S., \& Oshkurevich, O.E. (2007). Influence of forest operations on the formation of surface runoff and the development of erosion processes in Beskydy. Arboriculture and agroforestry, 111, 111-116 (in Ukrainian).

Olijnyk, V.S. (2013). The hydrological role of the forest in the Ukrainian Carpathians: Ivano-Frankivsk: NAIR (in Ukrainian).

Olijnyk, V.S., \& Tkachuk, O. M. (2015). Hydrological role of forest watershed of Precarpathians. Arboriculture and agroforestry, 127, 23-30 (in Ukrainian).

Perekhrest, S.M., Kochubei, S.G., \& Pechkovska, O. M. (1971). Natural disasters in the Ukrainian Carpathians and their control techniques. Kyiv: Scientific thought (in Ukrainian).
Pobedinsky, A. V. (1979). Water-protective and soil protection role of Forests. Moscow: Forestry (in Russian).

Polyakov, A. F. (1965). Effect of the main felling on the soil protection properties of beech forests. Moscow: Forestry (in Russian).

Resources of surface waters of the USSR. Basic hydrological characteristics. (1976). Leningrad: Gidrometeoizdat (in Russian).

Tsys, P. M. (1968). Geomorphology and neotectonics. The nature of the Ukrainian Carpathians. Lviv: Publishing House of Lviv University (in Ukrainian).

Chubatyy, O. V. (1968). Protective role of the Carpathian forests. Uzhhorod: Carpathians (in Ukrainian).

Chubatyy, O. V. (1984). Mountain forests are regulators of the water regime. Uzhhorod: Carpathians (in Ukrainian).

\section{Почвозащитная роль леса на водосборах Карпат}

\section{В.С. Олийник' ${ }^{1}$ Р.М. Витер²}

В комплексе многогранных функций леса весомое место принадлежит его почвозащитной роли. Однако количественная оценка противоэрозионных и водоочистных свойств карпатских лесов, особенно на водосборных бассейнах, в литературе почти отсутствует. Актуальной проблемой является установление критических и оптимальных в почвозащитном отношении показателей лесистости, как неотъемлемой предпосылки внедрения ведения хозяйства по водосборному принципу.

Цель исследований заключалась в количественной оценке почвозащитной роли лесистости горных водосборов 3 учетом местных природно-лесоводственных условий территории Карпат. Объектом исследований были 33 речные бассейны площадью от 25 до 6890 км² $^{2}$ средними высотами 450-1100 м н.у.м. и крутизной склонов 5-22 . Анализ естественных условий свидетельствует, что атмосферное увлажнение и крутизна юго-западного мегасклона Карпат больше, чем северо-восточного, поэтому твердый сток в первом случае интенсивнее, чем во втором. Показатели смыва почв и мутности рек существенно уменьшаются с увеличением лесистости водосборов. Этот процесс начинает проявляться с ее $12 \%$ уровня. С увеличением крутизны склонов почвозащитные

\footnotetext{
Олийник Василий Степанович - действительный член Лесной академии наук Украины, доктор сельскохозяйственных наук, профессор, заведующий кафедры лесоведения, Прикарпатский национальный университет им. В. Стефаныка, ул. Шевченка, 57, г. Ивано-Франковск, 76018, Украина. Тел.: +38-067456-75-94. E-mail: klz.pu.if.ua@ukr.net

Витер Роман Михайлович - кандидат сельскохозяйственных наук, доцент, доцент кафедры лесоведения, Прикарпатский национальный университет им. В. Стефаныка, ул. Шевченка, 57, г. Ивано-Франковск, 76018, Украина. Тел.: +38-097-378-7514.E-mail: viterrm@ukr.net
} 
свойства леса ослабляются. При крутизне склонов до $5^{\circ}$ лес, по сравнению с полем, уменьшает твердый сток в 53 раза, а при крутизне 10, 15 и 20ㅇ, соответственно, в 7,4, 4,5 и 3,4 раза.

Горные леса Карпат являются мощным почвозащитным фактором, способным уменьшать эрозионные процессы, по сравнению с полевыми угодьями, почти в семь раз, способствуя тем самым уменьшению мутности речных вод почти в 19 раз. Современная $(59 \%)$ лесистость горной системы уменышает интенсивность эрозионных процессов почти в два раза.

В пространственном отношении защитная роль леса изменяется в зависимости от крутизны и высоты горных склонов. На северо-восточном мегасклоне Карпат она сильнее выражена, чем на более крутом юго-западном. Влияние крутизны склонов в развитии эрозионных явлений достаточно ощутимое в нижних высотных полосах обеих мегасклонов (до 800 м н.у.м.) с антропогенно сниженной лесистостью (20-60\%). В верхней части гор (более 800 м н.у.м.) негативная роль горного рельефа в развитии эрозии элиминируется высокой лесистостью водосборов (60-80\%).

С целью уменьшения эрозионных процессов и улучшения чистоты природных вод необходима дифференцированная система лесоводственномелиоративных мероприятий. В нижней горной полосе основные из них - облесение крутосклонов и эродированных земель. В верхней - облесение участков лесомелиоративного фонда и поднятие антропогенно сниженной верхней границы леса на водосборах с лесистостью $<70 \%$. В обеих случаях очень важным является создание защитных полосных насаждений вдоль гидрографической сети и на обширных аграрных угодьях.

Ключевые слова: горные леса, водосборы, лесистость, эрозионные процессы, твердый сток, мутность воды, крутизна склона

\section{The role of forest in soil erosion controlling at the Carpathian catchment area}

\author{
V. Olijnyk ${ }^{1}$, R. Viter ${ }^{2}$
}

Soil protection function plays a significant role in a range of various forest functions. Nevertheless, the

Vasyl Olijnyk - the full member of the Forestry Academy of Sciences of Ukraine, Doctor of Agricultural Sciences, Professor, Head of the Department of Forestry. Precarpathian National University named after Vasyl Stefanyk. 57 Shevchenko str., Ivano-Frankivsk, 76018, Ukraine. Tel.: +38-067-456-75-94. E-mail: klz.pu.if.ua@ukr.net

Roman Viter - the candidate of agricultural sciences, associate professor, assistant professor of forestry department. Precarpathian National University named after Vasyl Stefanyk. 57 Shevchenko str., Ivano-Frankivsk, 76018, Ukraine. Tel.: +38-097-378-75-14. E-mail: viterrm@ukr.net quantitative evaluation of anti-erosion and water-purifying properties of Carpathian forests, especially of the catchment areas, is practically not described in the literature. The establishment of critical and optimal soil protection factors for forestry is an urgent issue, as an indispensable precondition for the forest management according to the catchment principle.

The objective of the research was to assess quantitatively the soil protection role of the forestland of the mountain watersheds, taking into account the local nature and forest conditions of the Carpathians. The object on which research focused are 33 river basins with an area of 25 to $6890 \mathrm{~km}^{2}$, with average altitudes of $450-1100 \mathrm{~m}$ asl. and slope steepness of $5-22^{\circ}$. The analysis of natural conditions indicates that the atmospheric humidity and steepness of the south-western mega slope of the Carpathians are greater than the northeastern one, and therefore the solid runoff in the first case is more intense than in the second. The indicators of soil erosion and river turbidity significantly decrease with an increase in the forest cover of watersheds. This process is going when forest cove as at least at $12 \%$ level. As the steepness of the slopes increases, the soil protection properties of the forest are weakened. With steep slopes up to $5^{\circ}$, the forest in comparison with the field reduces solid runoff by 53 times, and with the steepness of 10,15 and $20^{\circ}$, respectively, in 7.4, 4.5 and 3.4 times.

The Carpathian mountain forests are a powerful soil protection factor that can reduce erosion processes in comparison with field lands almost sevenfold, thus contributing to a decrease in river turbidity almost 19 times. The modern forest cover of $59 \%$ of the mountain system improves these processes twice.

In the spatial sense, the protective role of the forest varies depending on the steepness and height of the mountain slopes. On the north-eastern mega slope of the Carpathians, it is more obvious than in the steeper southwest one.

The influence of the slopes steepness on the soil erosion is quite noticeable in the lower high-altitude layers of both mega slopes (up to $800 \mathrm{~m}$ ) with anthropogenically reduced forest cover $(20-60 \%)$. In the upper lanes of mountains (more than $800 \mathrm{~m}$ ), the negative role of mountain relief on the development of erosion is eliminated by high forest cover of catchment areas $(60-80 \%)$.

In order to reduce erosion processes intensity and improve the purity of natural waters, a differentiated system of forestry-reclamation measures is required. In the lower mountain layer the main ones are the afforestation of steep slopes and eroded lands. In the upper part they are the afforestation of forest improvement plots and raising anthropogenically lowered upper boundary of the forest in the catchment with a forested area of $<70 \%$. In both cases, it is very important to create protective bands along the hydrographic network and lands with extensive agriculture.

Key words: mountain forests, catchments, forests, erosion processes, solid runoff, water turbidity, slope steepness 